\title{
HOW SOCIAL FACTOR DETERMINE INDIVIDUAL TAXPAYERS' TAX COMPLIANCE BEHAVIOUR IN MALAYSIA?
}

\author{
Nivakan Sritharan* \\ Universiti Malaysia Sarawak \\ Sahari Salawati \\ Universiti Malaysia Sarawak \\ Sharon Choy-Sheung Cheuk \\ Universiti Malaysia Sarawak
}

\begin{abstract}
The aim of this study is to clarify the role of social factors on individual taxpayers' tax compliance behaviour in Malaysia. Studies with similar topics express the fact that there still exists a gap in the developing countries that impact the decision making on tax compliance. Malaysia is a multi-racial and cultural country with social factors to impact on tax compliance. Some of the factors impacting are cultural impact, political affiliation, and religiosity, which are considered to be playing an important role in individual tax compliance behaviour. The researcher used a survey method of research design. For that the population targeted was the individual taxpayers across Malaysia. A sample of 419 respondents had been taken for this study, using a convenient sampling method. Pearson correlation and multiple regression analysis had been employed to analyse the data. The outcome of the study reveals that changes in government policies, referral groups, the role of LHDN, and political affiliation are the main important variables that determine individual taxpayers' tax compliance behaviour. This paper studied social factor variables, which finally fills the gap that existed in the literature and helps tax administration to develop effective compliance risk treatment.
\end{abstract}

Keywords: Tax Compliance; Tax Evasion; Social Factors; LHDN.

Received: 15 July 2019

Accepted: 4 September 2020

\section{INTRODUCTION}

\subsection{Background}

The "Income Tax Act 1967 (ITA)" is a mandatory law that seeks a certain amount of income from the salaries of every individual and from the profits of every business entities to be paid as tax to the government, since the payment of the income to the government is deemed a contribution to the government for the developments it carries out, for the services it provides to

* Corresponding author: Faculty of Economic and Business (UNIMAS); Phone: +60-1126808925; Email: srinivakan@gmail.com 
the nation and for keeping the economic equilibrium of the nation (Ahmed \& Kedir 2015). Hence, the role the Malaysian taxation plays is two folds: provision of 'economic benefits' to the nation, and the provision of 'social benefits' to the nation. The government takes charge to provide the economic benefits to the nation by collecting the revenue by means of withdrawal from the economy, and by spending the earned income to the national economy (Ministry of Finance Malaysia, 2019). It may inject back a part of the revenue into the economy; it may provide goods and services to the nation, or it may use the revenue to achieve its objectives, said in the budget or any other government agendas.

Since gaining independence, Malaysia has practiced its own income tax collection under the 'Official Assessment System' (OAS), wherein the taxpayers and their tax payables are evaluated by the tax authority of Malaysia, 'IRBM'. The manual practice of the 'OAS' has been transformed into a new system called 'Self-Assessment System' (E-filing) by the Prime Minister Tun Dr. Mahathir Mohamad in the year 2001 and in the year 2004 for corporate tax and personal tax respectively. The pre-SAS system, 'Official Assessment System' (OAS) and the SAS system are different from the SAS system, which is fully and solely used by the taxpayers themselves. Every citizen draws his/her own tax payables, receivables (income tax return), and determine whether they are eligible for exemptions and reliefs. This system plays a two-way role, where the taxpayers have the responsibility to perform all the taxation procedures before they are evaluated by the tax authority. Due to the responsibility and the trust given to the taxpayer, the tax compliance rate in the country, somehow, depends on the behavior of every individual taxpayer. A study, conducted right after the introduction of the 'Self-Assessment System' (SAS) and measured the perception of the taxpayers towards the 'Self-Assessment System', shows the fact that the taxpayers are more comfortable with the SAS than with OAS (Kasipillai, 2004). Further, Chukwudi (2017) and Kasipillai (2002) studies that tax knowledge is essential for the voluntary tax compliance system.

Malaysia's total gross income is moving upward steadily (Refer to Figure 1) while the tax revenue of Malaysia has been declining (Refer to Figure 2) dramatically for the past two decades (World Bank, 2020). One of the main reasons for the declining trend in tax revenue is the tax non-compliance by the residents (Esteller, Piolatto \& Rablen, 2017). The decline in the national revenue has put the nation into economic instability, and there is a need for finding the cause for the decline in the national revenue. 'Non-compliance of tax' is social destruction, as it reduces the national revenue, misleads the labor market, and declines the strength of the state stability by encouraging cheat and fraud (Kiow, Salleh \& Kassim, 2017). Tax non-compliance is a violation of tax laws and is classified into three main classes, known as crude form, manipulation, and adulteration (Kasipillai \& Shanmugam, 1995). Under-reporting, the actual income, and overstating the expenditures are a crude form of non-compliances (Berens \& Schiller, 2016). 
Figure 1: Gross National Income of Malaysia

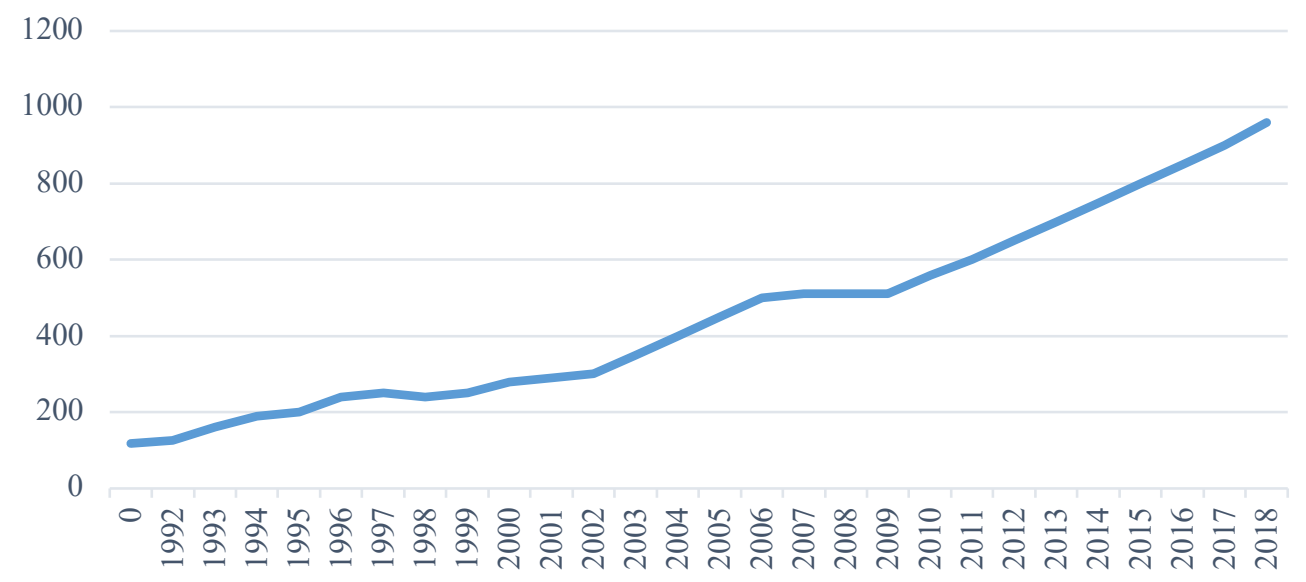

Source: World Bank (2020).

Figure 2: Malaysia, Tax Revenue Collection from, 1996-2017

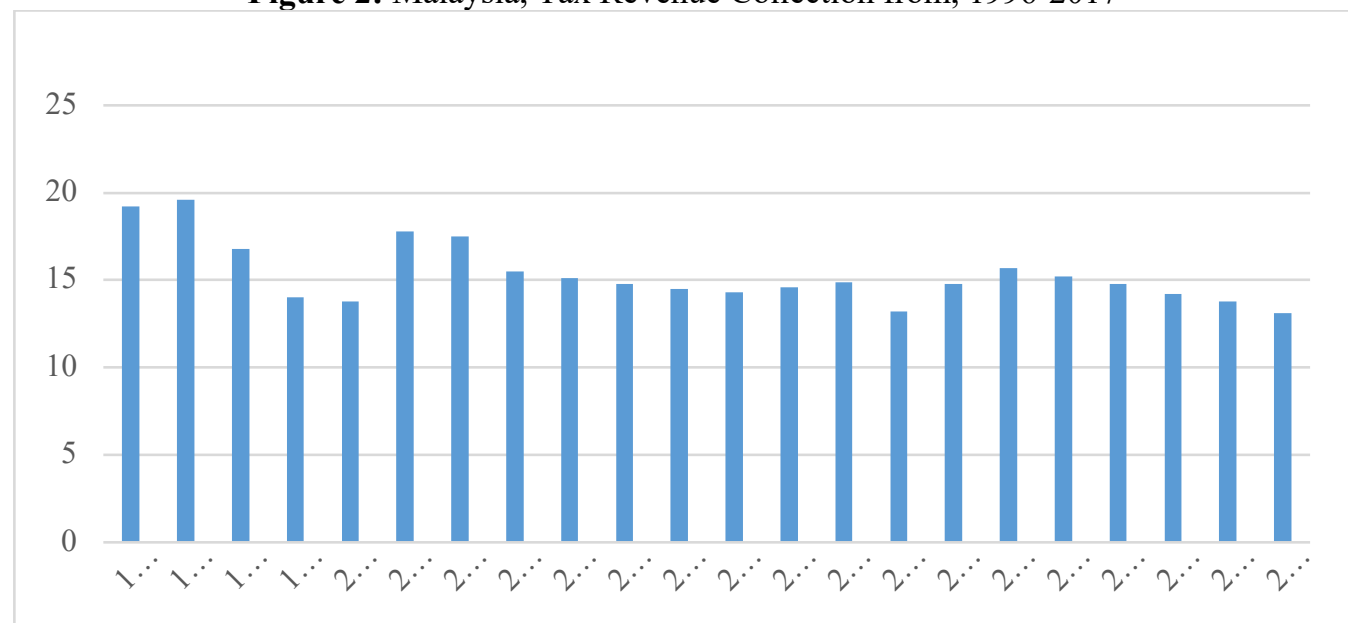

Source: World Bank (2018).

Non-compliance with the tax system is a growing global issue, constructing a severe threat on the national economy and leading to the unstable government fiscal capacity (Chong \& Arunachalam, 2019). To support the research gap with real examples, top headlines taken from Malaysian Newspapers' headlines are evidenced. Recent Major news reports were delivered to the local medias by Inland Revenue Board of Malaysia (LHDN) as follows; IRB 'Cheated of billions' (Nokman, 2017), 100\% penalty from next year for income tax dodgers (LHDN reveals cheating, 2017), Tax dodgers may be put in credit blacklist (Shah, 2017), Inland Revenue warns of syndicate out to cheat tax payers (Inland Revenue Warns, 2017), Malaysia Tax Payers' Responsibilities (Grewal, 2019). Government Accountability Office (GAO) (2011), released in report that people of United States see tax as a complex subject and this complexity contribute 
more on non-compliance level. Most individual taxpayers hesitate to pay taxes, and so they perform a variety of actions to cut-down their tax liabilities (Ahmed \& Kedir, 2015). One of the main causes is the tax non-compliance behavior of taxpayers. According to McBarnett's tax determinants behavior model, tax compliance (capitulated, committed and avoidance) and noncompliance (tax evasion) are the major components of a taxpayer's behavior (Alabede, Ariffin \& Idris, 2011).

Recent empirical studies focusing developing countries are rare and this paper will contribute to new findings to the field of taxation studies. Thus, the purpose of this paper is to examine the determining social factors towards individual taxpayers' tax compliance behavior in Malaysia. A very recent study by Chukwadi (2017) on taxation suggests to the future researchers "More research is needed on the relation between the taxpayer and the government in which lack of evidence limits the analysis of direct policy changes". According to two researchers Modugu and Anyaduba (2015) explain, "Changes of government policies might also impact tax compliance behavior. For example, unlike in the UK, in Malaysia, petrol prices and some basic needs like sugar, wheat flour, rice and cooking oils are controlled by the government and the prices regularly increase according to global economic and government financial situations". Palil (2010), says other determinants such as political affiliation, cultural influence and religiosity are more relevant to research for Malaysian context. There are limited studies around the world focusing developing countries that focus how social factors impact the individual taxpayers' tax compliance behavior. Thus, the above-mentioned evidence confirms the existence of research gap and place a necessity to examine the social factors that determine the individual taxpayers' tax compliance behavior in Malaysia. This study present evidence of how and which variables have impact on individual taxpayers' tax compliance behavior.

This paper proceeds as follows: Section 2 literature review discusses theoretical arguments and hypothesis development, section 3 methodology, section 4 findings and discussions and section 5 conclusion with recommendations.

\section{LITERATURE REVIEW}

\subsection{Tax Knowledge}

Knowledge of tax law is assumed to be the most fundamental requirement, when considering the attitudes of individual taxpayers (Eriksen \& Fallan, 1996), and to form a significant and positive relationship with effects on tax fairness (Mukhlis, Utomo \& Soesetio, 2015). Even though limited researches are conducted in this field of study, some of them conclude that education plays an important role as a variable, because the application on the 'Self-Assessment System' requires the user to acquire tax knowledge (Harjito, Omar, Ariffin \& Latiff, 2005; Kasipillai, 2004). Filing tax returns within the due time frame, honestly reporting their tax matters, and correctly computing the tax liabilities essentially require a certain level of tax knowledge of every taxpayer (Loo, Evans, \& Mckerchar, 2010). Kasipillai (1999) mentions that acquiring tax knowledge may twist the uncertainty of compliance with tax system into having a fair perception of tax system because the lack of tax knowledge may or may not lead to unintentional noncompliance with the tax system. If the knowledge alters the myths and misperception, the 
individual attitudes towards taxation also change while the tax regulations remain unchanged (Eriksen \& Fallen, 1996). Few aspects of individual attitudes towards taxation; tax ethics and the fairness of tax system, determine the tax evasion to be performed (Bhavish, Hema \& Akshay, 2017).

\subsection{Role of Tax Authority (LHDN)}

A very recent study by Chong and Arunachalam (2019) explains that Malaysian citizens' trust in tax authority is a mediator. Experiments reveals that the people, who are treated with good acknowledgement and fair treatment by the authorities, tend to comply more with the tax system (Braithwaite, 2009; Delaney \& Harmon, 2009). Different countries adopt different tax systems. Whereas, most of the developed countries and a few of the developing countries adopt the 'SelfAssessment System', making it easy for them to apply and practice (Serem, Robert \& Phillip, 2017). This mixed adoption of the tax system around the world has given no standard findings to discover the relationship between the role of tax authority and the taxpayer's compliance behavior (Palil, Hamid, \& Hanafiah, 2013). The government plays a main role in introducing laws, and under the decentralizing system of powers in a country, dealing in the tax collection is entrusted to agents in every country (Wang, 2015). This administrative system might affect the tax authority when the government of a country earns a negative name from the people (Richardson, 2008). Among the three types of fairness in taxation, Organization for Economic Cooperation and Development (OECD) (2010) Explains that two of them are related, as to how the tax authority deal with the taxpayers: the 'procedural fairness' (the perception that tax authority is fair in dealing with clients) and the 'retributive fairness' (the perception that tax authority is fair in applying penalties). Murphy (2004) emphasizes that if a situation happens, whereby the taxpayers do not trust the administration, there will an increase in the level of noncompliance. Alm, Cherry, Jones and Mckee (2010); Reeson and Dunstall (2009) discus that the taxpayers' good perception on fairness and their trust in the tax authority are particularly the important tools to reduce tax non-compliance.

New Economics Foundation (NEF) (2005), further supports it with similar facts by explaining, as "The better the taxpayers are treated by the authority, the less they become tax non-compliant", that is, if the taxpayers are treated fairly and respectfully by the tax authority, there will be more chances for the taxpayers to be tax compliant. If this paper finds a significant relationship between tax authority and compliance behavior, then proposed model; "Right from the Start", adopted by Swedish Tax Agency will be recommendable to the Inland Revenue Board of Malaysia as well. Swedish Tax Agency (STA) (2005) introduced that, "Right from the Start" "is a compliance method based on the principle that the tax authority has a role to play in creating an environment which encourages compliance".

\subsection{Political Affiliation, Cultural Influence and Religiosity}

According to the literature review, the political factors, such as the stability of the government, or the political policies, and the ruling government party determine the tax compliance in a country (Riah, 2004). It has been assumed in the previous studies that the political affiliation might influence an individual to be in favor of or against the tax system in the country (Palil, 2010). Further said, if an individual has an affiliation with or favors the current ruling party, the individual might be chosen to be a compliant with the tax system because the person thinks and 
believes that the government is trustworthy. This situation might occur vice versa, if the person does not have a good perception towards the government, which is led not complying with the tax system (Bhavish et al., 2017). Furthermore, Keen, Kim and Varsano (2006) explains that the political and the tax administration highly correlate with the tax evasion. According to the recommendation of author (Palil, 2010)), the future studies, which are related to taxpayers' behaviors, should consider and explore the factors of political affiliation, cultural influence and religiosity.

\subsection{Changes in Government Policies}

Previous studies conclude that Malaysian tax laws are very complex to understand and to adopt and is rather confusing to the users as the laws are frequently going through changes, amendments, and removals (Kasipillai, 1999). As a result, the researcher assumes that it can lead the taxpayers to noncompliance with the tax system (Olaoye, 2017). However, it is not yet clear to the researchers to conclude whether the simplification of Malaysia's tax law and regulations may be effective against non-compliance (Kiow et al., 2017). It is noticeable that a number of public rulings have announced changes, amendments, and removal of rules and regulation since 2000 (Pope \& Jabbar, 2011). According to (Hanefah, 1996), the Malaysian corporate tax system as well as the personal tax system are increasingly complex to the taxpayers, due the changes effected either in the law or to the new introduction of law. Further, OECD (2010) categorized the fairness of taxation, and one among the three refers to the government policy implementation, distributive fairness (the perception that the government acts correctly and wisely in spending money through the implementation of relevant and appropriate policies).

\subsection{Referral Group}

The studies so far discussed that people always are ready to react to social norms, and the behaviour of others strongly influences an individual's choice (OECD, 2010). This effect simply highlights the relationship between the social groupings and the individual's decision-making (Oladipupo \& Obazee, 2016). Peers or neighbours, who closely live in a community, exert more influence on those who are far from an individual (Behavioural Insights Team (BIT), 2012). If an individual has a perception that the tax evasion is impossible and that the majority of people around the community are more compliant, the situation discourages the individual in the evasion of tax Wenzel (2001a, 2001b).

\subsection{Kelman's Social Influence Theory}

Kelman (1958) proposed that an individual's attitude, action, beliefs, and the subsequent reactions, or behaviours are influenced by the referral of others over three stages: compliance, identification and internalization. Compliance occurs when an individual starts to accept the external influence. The external social factors, such as the government, peer groups, or the relevant authorities, heavily determine an individual's decision making (Venkatesh \& Davis, 2000). Kelman (2006) explained that the different interaction environments lead, in the long run, on the individual level to corresponding forms by taxpayers for instance enforced tax compliance, voluntary tax cooperation, and committed tax cooperation. 
Figure 2: Conceptual Framework

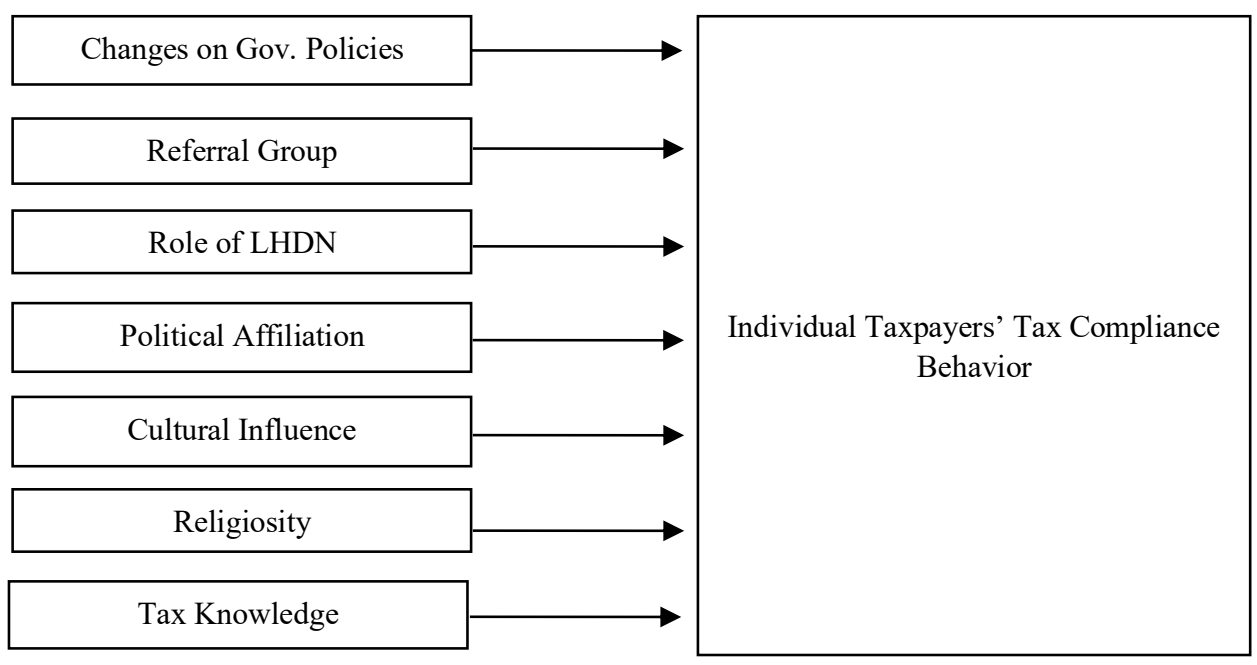

H1: There is a significant relationship between changes in government policies and individual taxpayers' tax compliance behavior

$\mathrm{H} 2$ : There is a significant relationship between better referral groups and individual taxpayers' tax compliance behavior

H3: There is a significant relationship between role of tax authority (LHDN) and individual taxpayers' tax compliance behavior

H4: There is a significant relationship between political affiliation and individual taxpayers' tax compliance behavior

H5: There is a significant relationship between cultural-influence and individual taxpayers' tax compliance behavior

H6: There is a significant relationship between religiosity and individual taxpayers' tax compliance behavior

H7: There is a significant relationship between tax knowledge and individual taxpayers' tax compliance behavior

\section{METHODOLOGY}

\subsection{Data Measurement}

A survey questionnaire distributed targeting individual salaried taxpayers from both public, private sectors and sole proprietors across Malaysia using convenient sampling method. The population of this study is the working adult taxpayers across Malaysia. Department of Statistics Malaysia mentions that around 14 Million (14,00,000) people are employed. According to (Krejce \& Morgan, 1970), the sample size is selected based on the table discussed under their studies. If the population is greater than seventy-five thousand, a sample size of three hundred and eighty-four (384) is reasonable. A survey questionnaire used to collect data from the 
population. A questionnaire is a pre-formulated written set of questions to which respondents record their answers, usually within rather closely defined alternatives. The questionnaire was prepared in English containing three sections. In order to make ease of the access and completion of surveys, Google E-survey and printed hardcopies were used. Normally, companies in Malaysia with large number of employees consist employees with different ethnicity and different level of salaries, which avoid the bias, irrupts on choosing the low- and higher-income level taxpayers. This survey was carried out during March to May 2019 in Malaysia. A total number of 2,400 Google E-surveys were sent to various individual taxpayers through Malaysia whose e mail addresses were pulled out from Staff Directories of every organization's official websites. At the meantime, 100 printed questionnaires were distributed in Kuching and nearby suburbs to self-employed businessmen or sole proprietors who do not have the official contact facilities.

The first section of the questionnaire consisted demographic information such as age, gender, income level, education background, race and some other background information about the respondent's tax history and experience. Section B part (1) tested the level of tax knowledge the respondents have. (Loo, 2006; Palil, 2010) designed to test the level of knowledge by subdividing the variable into different categories: knowledge about taxpayer's rights and responsibilities, Income from employment, income from dividend and interest, personnel relief, child relief, rebates and knowledge about penalties and offences. This set of questions require the respondent to rate their awareness by scaling from 0 to 2 specifies not sure ( 0 score), unaware ( 1 score) and aware ( 2 score) respectively. A score of 2 is allocated for respondent's scale for aware and 1 for unaware. Section B part (2) contains the social determinants questions. The determinants are divided into six categories: government spending, referral group, role of LHDN, political influence, Cultural influence and religiosity. This set of questions require the respondent to rate their opinion by scaling from 0 to 2 specifies not sure $(0$ score $)$, disagree ( 1 score) and agree ( 2 score) respectively. A score of 2 is allocated for respondent's scale for agree which is compliant and 1 for disagree which is non-compliant. Section C contains tax compliance questions. This section includes six different scenario typed questions related to compliance behavior with tax system. (Ching, 2013) justify that in order to reduce the dishonesty of respondents' answers, an indirect tax related questions should be adopted in the form of scenario. Scenario based questions establishes situations where respondents are asked to make decision for one choice. Respondents need to answer "YES/ NO" for the scenario-based question imagining them on the same position said in the scenario. Followed by respondents are required to tick the probability (from low probability to high probability) that the respondent will undertake the same action said in the scenario using 5 points Likert scale. The Likert scale is designed to examine how strongly subject agree or disagree with statements on a 5 points scale (Sekaran, 2005).

To measure the questions, $40 \%$ is allocated for Yes, No questions where NO Answer=2 score and YES answer=1 score. The "YES/NO" type question does not require the respondents to spend much time to establish their decision, but the probability question do require the respondents to spend few time to derive their decision. As the Probability questions require the respondents to decide their decision, it is allocated with $60 \%$ where probability $1=5$ score and probability $5=1$ score. This percentage allocation for the questions increases the results validity. If a respondent answer "Yes" and tick " 5 " as the probability of being carry out the same action said in the scenario, he/ she will be scored $(1 * 0.4)+(1 * 0.6)=1$ score that indicate the respondent is highly non-compliance. If a respondent answer "No" and tick " 1 " as the probability 
of being carry out the same action said in the scenario, he/ she will be scored $(2 * 0.4)+(5 * 0.6)=$ 3.8 score that indicate the respondent is highly compliance.

\subsection{Data Analysis}

The descriptive analysis helps to represent the characteristics of variables (Piaw, 2013). (Ahangar, Bandpey \& Rokny, 2011; Fagbemi, Uadiale \& Noah, 2010; McGee \& Gelman, 2009) were some of the researchers have already applied the similar statistics in their studies. The reliability of measure specifies the extent to which it is without bias and confirms consistent measurement across time and across the various items in the instrument. The reliability of measure is an indication of the stability and consistency (Sekaran, 2000). The data also tested by using the Pearson correlation analysis and multiple regression analysis using SPSS statistic software. The equation is estimated using the multiple regression-based framework.

$$
\text { TCOM }=\beta+\beta_{1} \text { GOVP }_{\mathrm{i}}+\beta_{2} \text { RFGRUP }_{\mathrm{i}}+\beta_{3} \mathrm{RLHDN}_{\mathrm{i}}+\beta_{4} \mathrm{POLI}_{\mathrm{i}}+\beta_{5} \mathrm{CUL}_{\mathrm{i}}+\beta_{6} \mathrm{RLIG}_{\mathrm{i}}+\beta_{7} \mathrm{TK}_{\mathrm{i}}+\varepsilon
$$

Whereas;

TaxCom is refers to Tax Compliance Score, $\beta$ is refers to population coefficient, GOVP, RFGRUP, POLI, CULTI, RELIG and TK are referring to Government Spending, Referral Group, Role of LHDN, Political Affiliation, Cultural Influence, Religiosity and Tax Knowledge respectively. $\varepsilon$ is refer to random error term.

\section{RESULTS AND DISCUSSION}

Programmed Google E-Surveys were sent to respondents whose e mail address were taken from their respective workplace official website under the staff directory. 2,400 E-mails were sent and 100 questionnaires were distributed by hand in Kuching and nearby suburbs. 647 e mails were not delivered due to incomplete e mail address or non-active or the employee resigned or no more work at that workplace. Out of 1,853 successfully delivered e mails 319 responses along with 100 by-hand responses were received representing $22.6 \%$.

The respondents consist 237 Females and 182 males which are 57\% and 43\% respectively. Most of the respondents are Malay community representing 196 (47\%) followed by Chinese $84(20 \%)$, Indians $81(19 \%)$. The rest $14 \%$ representing others who are none of the discussed main three communities but including Dayak communities and foreign employees in Malaysia. Four age groups were designed for data collection and which are set up with the age gap of 10 years in between. The majority respondents are between 31 and 40 years old representing 39\% (165 respondents). At the same time, the lowest respondents age group were 51 and above representing 16\% (65 respondents).

Furthermore, 61\% (257 respondents) of the respondents are married followed by 31\% (142 respondents) singles and 5\% (20 respondents) divorced or separated. Majority respondents are followers of Islam religion representing 54\% (225 respondents). This may be due to Malays, some Indians and Other communities who are also followers of Islam in Malaysia. Followed by Cristian and Hindu respondents represents $17 \%$ each representing 70 respondents and 71 
respondents, respectively. 10\% (42 respondents) are followers of Buddhism and other religious which are not popularly followed in Malaysia represents 3\% (11 respondents).

297 (71\%) respondents hold a good academic qualification (Degree/ Professional). Second largest group hold Master/Phd, 91 respondents $(22 \%)$, which is higher than Degree qualification. 22 respondents (5\%) reported holding Certificate/ Diploma level qualification whereas only 9 respondents (2\%) hold SPM/STPM qualification. Majority respondents earn RM 5,001 and RM 7,000. The combination of respondents between RM 3,001 and RM7,000 make up 76\% (317 respondents). At the same time, the combination of respondents' income level more than RM 7,001 represents $20 \%$ ( 82 respondents). The lowest group among other respondents are reported representing less than RM 1,000 were 5\% (20 respondents). The tax chargeable income in Malaysia commence from RM 5,001 and above. Therefore, the classification of income group helped to track the number of income makers who are eligible for tax payment.

Majority of the respondents $81 \%$ (338 respondents) have never attended any tax courses and $70 \%$ of the respondents (292 respondents) have no experience of being audited by LHDN. Meanwhile, $19 \%$ of respondents (81 respondents) reported that they have attended tax courses. Moreover, $30 \%$ of the respondents (127 respondents) reported that they have experience being audited by LHDN.

\subsection{Reliability Test}

Table 1: Cronbach's Alpha Reliability Test (Tax Knowledge)

\begin{tabular}{ccc}
\hline \hline Cronbach's Alpha & $\begin{array}{c}\text { Cronbach's Alpha Based on } \\
\text { Standardized Items }\end{array}$ & N of Items \\
\hline .661 & .615 & 7 \\
\hline \hline
\end{tabular}

Table 2: Cronbach's Alpha Reliability Test (Determinants Questions)

\begin{tabular}{ccc}
\hline \hline Cronbach's Alpha & $\begin{array}{c}\text { Cronbach's Alpha Based on } \\
\text { Standardized Items }\end{array}$ & N of Items \\
\hline .691 & .645 & 6 \\
\hline \hline
\end{tabular}

Table 3: Cronbach's Alpha Reliability Test (Tax Compliance Questions)

\begin{tabular}{ccc}
\hline Cronbach's Alpha & $\begin{array}{c}\text { Cronbach's Alpha Based on } \\
\text { Standardized Items }\end{array}$ & N of Items \\
\hline .780 & .956 & 6 \\
\hline \hline
\end{tabular}

A reliability test is conducted to ensure the internal consistency and stability of the testing items and measure to what extent the items in the questionnaire are biased (Hong, 2005). Table 2 shows the Cronbach's Alpha score for Section B, part (1) (Tax Knowledge Questions) resulting 0.661, Table 3 shows the score for Section B, part (2) determinants questions resulting 0.691. Further, table 4 shows the tax compliance behaviour scenario-based questions resulting 0.780. According to Eriksen and Fallen (1996), Cronbach Alpha more than 0.5000 indicates that instruments used in the questionnaire are valid and also a high degree of reliability. 


\subsection{Correlation between Variables}

Table 4 illustrates the Pearson's correlation output between independent variables known as changes on government policies (GOVP), referral group (RGRUP), the role of LHDN (RLHDN), political affiliation (POLI), cultural influence (CUL), religiosity (RLIG) and tax knowledge (TK) and dependent variable as individual taxpayers' tax compliance behavior (TCOMP). The correlation coefficient between each independent variable and tax compliance was noted between the range $\mathrm{r}=.009$ to $\mathrm{r}=.573$. Based on the outcome presented in Table 4, cultural influence is the only variable that has an average positive and significant relationship with individual taxpayers' tax compliance behavior in Malaysia $(\mathrm{sig}=0.000, \mathrm{p}<0.01)$. At the same time, other variables express a positive relationship but with weaker correlation at $10 \%$ significant level. The mentioned variables with positive correlation explain that if the changes on government policies, referral group, the role of LHDN, political influence, or cultural influence is in an upward trend, the level of individual taxpayers' tax compliance behavior will be increased as well and the relationship is confirmed with $10 \%$ significance level $(p<0.01)$. Moreover, they emphases the importance of considering the particular variables in an effort to improve individual taxpayers' tax compliance behavior. In contrast, variables such as religiosity and tax knowledge are recognized as a negative weaker relationship with individual taxpayers' tax compliance behavior in Malaysia. Further, it illustrates that if religiosity or tax knowledge among taxpayers is in an upward trend, then the level of individual taxpayers' tax compliance behavior will be decreased. But this relationship is affirmed by significance level, $\mathrm{p}>0.01$, in which they are insignificantly and negatively correlated with individual taxpayers' tax compliance behavior in Malaysia.

Table 4: Correlation between Social Factors and Tax Compliance Behaviour

\begin{tabular}{ccc}
\hline \hline Variables & Coefficient Correlation & Sig \\
\hline Changes on Government Policies & $.307^{* *}$ & .003 \\
(GOVP) & $.373^{* *}$ & .000 \\
Referral Group (RGRUP) & $.350^{* *}$ & .000 \\
Role of LHDN (RLHDN) & $.347^{* *}$ & .000 \\
Political Affiliation (POLI) & $.573^{* *}$ & .000 \\
Cultural Influence (CUL) & -.034 & .485 \\
Religiosity (RLIG) & -.009 & .868 \\
Tax Knowledge (TK) & 1 & \\
Tax Compliance (TCOMP) &
\end{tabular}

Notes: ** Correlation is significant at the 0.01 level (2-tailed).

\subsection{Multiple Regression Analysis}

Table 5: Regression Analysis

\begin{tabular}{ccccccc}
\hline \hline Variables & Beta & Std. Error & t & Sig & Tolerance & VIF \\
\hline (Constant) & 9.331 & 0.454 & 13.096 & 0.000 & & \\
Changes on Gov. & 1.079 & 0.168 & 6.417 & 0.000 & .972 & 1.095 \\
Policies & & & & & & .933 \\
Referral Group & 0.806 & 0.086 & 9.257 & 0.000 & .972 & 1.025 \\
Role of LHDN & 1.062 & 0.207 & 5.126 & 0.000 & .960 & 1.086 \\
Political Affiliation & 1.479 & 0.122 & 11.95 & 0.000 & .960
\end{tabular}




\begin{tabular}{ccccccc}
\hline \hline Variables & Beta & Std. Error & t & Sig & Tolerance & VIF \\
\hline Cultural Influence & 1.049 & 0.148 & 7.088 & 0.000 & .964 & 1.029 \\
Religiosity & -0.024 & 0.085 & -0.252 & 0.751 & .976 & 1.063 \\
Tax Knowledge & -0.165 & 0.192 & -0.861 & 0.394 & .921 & 2.047 \\
\hline \hline
\end{tabular}

Notes: a. Dependent Variable: Tax Compliance.

Table 6: Regression analysis on the impact of the independent variables and tax compliance

\begin{tabular}{|c|c|c|c|c|c|}
\hline Model & $\mathbf{R}$ & R Square & Adjusted R Square & $e^{\text {Std. Error of the }} \begin{array}{c}\text { estimate } \\
\text { estimate }\end{array}$ & F Change \\
\hline 1 & $.649^{\mathrm{a}}$ & .442 & 0.420 & 3.28606 & 303.8 \\
\hline
\end{tabular}

According to the regression output Table 5 above, all the variables examined in the study are relevant since the tolerance value of more than 0.1 as well as the VIF (Variance Inflation Factor) factors are all below the benchmark 10. These benchmarks under statistics explain that there is no multi-collinearity among variables examined. Moreover, the P-value of 0.0000 reveals that the model is statistically significant as a whole. According to Table 5, if the independent variables remain constant, the level of individual taxpayers' tax compliance will have estimated at 9.331 units. The value of $\mathrm{R}$ Square was .442, while the value of adjusted R Square was .420. The observed and the predicted values of the dependent variable (TCOM) are represented by R which is 0.649 . Therefore, $64 \%$ of the explanatory variables had a relationship with individual taxpayers' tax compliance behavior. While, $\mathrm{R}$ Square indicates that the independent variables (Social Factors) only explained $44.2 \%$ variation in Tax Compliance while the rest $55.8 \%$ is explained by variables which are not covered by this study such as economic factors and demographic factors.

Further, changes in government policies has a positive $(\beta=1.079)$ and significant relationship with tax compliance behavior. Therefore, H1 (There is a significant relationship between changes in government policies and tax compliance behavior) is accepted. The positive relationship expresses that a better change in government policies introduce will increase an individual taxpayer's tax compliance level. The favorable and better introduction of government policies will impress the taxpayers (Olaoye, 2017). The better perception individual has towards the introduction of government policies will increase the tax compliance level (Zandi \& Elwahi, 2016). A country's administrative stability and ruling government party are assumed to be a significant factor in determining individual taxpayers' tax compliance behaviour (Palil \& Mustapha, 2011). This study found that better changes in government policies have not negatively associated with individual taxpayers' tax compliance behaviour.

The Referral group shows a positive $(\beta=0.806)$ and significant relationship with tax compliance behavior. Hence, $\mathrm{H} 2$ (There is a significant relationship between referral group and individual taxpayers' tax compliance behavior) is accepted. The positive relationship reflects that a better positive referral group will increase an individual taxpayer's tax compliance level. If an individual who lives in an environment where others comply honestly with the tax system will eventually discourage the individual from tax non-compliance (Oladipupo \& Obazee, 2016). Peer referral influences individuals in Malaysia on their decision making (Chong \& Arunachalam, 2019). Similar studies conducted by (Wenzel, 2005) also support a similar outcome and claim that if a taxpayer believes tax compliance is widespread and agreed by his peer group, they are 
also more likely to be compliant. To support with empirical evidence, (Ho, Loo, \& Lim, 2013) found that Chinese taxpayers in China use relationship-based reasoning to judge tax compliance issues. If most of the group members comply with the tax system, it is more likely that an individual in the group will have a greater level of tax compliance (Kiow et al., 2017).

The role of LHDN shows a positive $(\beta=1.062)$ and significant relationship with tax compliance behavior. As per the results, H3 (There is a significant relationship between the role of tax authority (LHDN) and individual taxpayers' tax compliance behavior) is accepted. The positive relationship informs that the better role the tax authority (LHDN) performance will increase the individual taxpayers' tax compliance level. A similar outcome was claimed by other studies in which found if the administration reduces the complexity, taxpayers tend to comply more (Alm \& Togler, 2006; Walsh, 2012). (Baldry \& Kasipillai, 1998) found that better interactions Inland Revenue Board (LHDN) performs with taxpayers also influence better way with tax compliance. It is also suggested that the Malaysian tax compliance level may increase if the tax collection authority upgrades the relevant technology for the sake of taxpayers (Pope \& Jabbar, 2011). The user-friendly E-Filing portal or easily accessible E-Filing form through smartphones devices may be the relevant technological advancement currently needed (Serem et al., 2017).

Political affiliation has a positive $(\beta=1.479)$ and significant relationship with tax compliance behavior. Thus, $\mathrm{H} 4$ (There is a significant relationship between political affiliation and tax compliance behavior) is accepted. The mentioned positive relationship further explains that a better and positive political affiliation or influence the taxpayer has will encourage them to comply with the tax system. If the taxpayer has a favorable stand for the ongoing government, the chances for the taxpayer to comply with the tax system are high. Hasseldine and Hite (2003) used a randomized telephone survey and found that political party affiliation has strongly impacted taxpayer's tax compliance behavior in the United States. Later studies demanded that studies about political affiliation in developing countries are required to be researched since the factor is predicted as an important variable (Palil \& Mustapha, 2011). Hence, this study reveals that higher political affiliation does not have a negative relationship with individual taxpayers' tax compliance behavior.

Moreover, the cultural influence result also has a positive $(\beta=1.049)$ and significant relationship with tax compliance behavior. Hence, H5 (There is a significant relationship between culturalinfluence and tax compliance behavior) is accepted. Again, the positive relationship between these two variables explains that the better cultural influence a taxpayer adopts or practice will increase the tax compliance level. If a taxpayer is influenced by the culture, he/she adopt on the matter of the national obligation, the taxpayer will comply more with the tax system than evade (Kiow et al., 2017). Earlier studies recommended that future researchers explore how culture impacts tax compliance behavior in developing countries (Luttmer \& Singhal, 2014). As per a previous study, a country that has high uncertainty of non-compliance, and low individualism, are more likely to engage tax non-compliance (Gupta, 2017). This study resulted that better cultural influence encourages individual taxpayers' tax compliance behavior. Similar to the study results, the earlier researcher conducted in developed countries claimed that culture and culturerelated differences may have a significant relationship on determining the individual taxpayers' tax compliance behavior (Chan, Troutman \& Bryan, 2000; Coleman \& Freeman, 1997; Riahi, 2004). Torgler (2007) found that culture could influence tax compliance behaviour in countries such as Switzerland, Belgium, and Spain. Additionally, a similar fact is also supported by other 
researchers who confirmed that a positive relationship exists between culture and taxpayers' tax compliance behaviour (Roberts, Hite, \& Bradley, 1994)

Religiosity has a negative $(\beta=-.024)$ and an insignificant relationship with tax compliance behavior $(p>0.01)$. Therefore, H6 (There is a significant relationship between religiosity and tax compliance behavior) is rejected. For each unit of increase in religiosity, there is a 0.024 decrease in tax compliance level. Further, the extreme adoption of religious beliefs will decrease the tax compliance level among taxpayers. Religiosity is defining by itself a negative or too extreme level of religious adoption. If a taxpayer is influenced by an extreme or negative adoption of religious believes, the chances for taxpayers to comply with the tax system will be low. Earlier studies reveal that people with stronger religious believes can determine taxpayers' tax compliance behavior. This claim also supported by other earlier studies carried out in countries such as Austria (Torgler, 2005); Australia (Torgler, 2004); Canada (Torgler, 2003); the Netherlands (Ross \& McGee, 2011); and some European countries (Torgler, 2006, 2007). Therefore, it was hypothesized in this study that there is a significant relationship between religiosity and individual taxpayer's tax compliance behavior. In contrast, this study found that religiosity has no significant relationship with individual taxpayers' tax compliance behavior. Further, it reveals that better adoption of religious beliefs encourages individual taxpayers' tax compliance behavior (Grasmick, Bursik \& Cochran, 1991; Petee, Milner \& Welch, 1994; Welch, Title, \& Petee, 1991). This results also similar to other studies by (Welch, Xu, \& Magro, 2005) claims that religiosity has no significant impact on tax compliance behaviour.

Most of the research studies suggested that high tax knowledge would increase voluntary tax compliance (Kirchler, Hoelzl \& Wahl, 2008; Loo, 2006; Lymer \& Oats, 2009; Marziana, Ahmad, \& Deris, 2010). Thus, it is hypothesized that there is a significant relationship between tax knowledge and individual tax compliance behavior. In contrast, (Amran, Aripin \& Kasipillai, 2013) found that tax knowledge has a negative relationship with tax compliance behavior. They raise a claim by saying the fact that a higher level of tax knowledge may encourage the taxpayers to identify the loopholes in the tax system and regulations that result in tax evasion or tax avoidance or tax non-compliance. However, this study found that tax knowledge has no significant relationship with individual taxpayers' tax compliance behavior. Therefore, H7 (There is a significant relationship between Tax knowledge and tax compliance behavior) is rejected. This paper supports other research studies by justifying that tax knowledge has a negative relationship with individual taxpayer's tax compliance behavior $(\beta=-0.165)$. For each unit increase in tax knowledge, there is a 0.165 unit decrease in the tax compliance level. This result consistent with an earlier study in which Haris (1989) argued that tax knowledge has no direct significant relationship on individual taxpayer's tax compliance behavior. It is understandable that tax knowledge under the Self-Assessment System in Malaysia may not require tax knowledge for the form completion purpose since all the numerical values are instructed and specified in the E-Filing portal. The maximum amount and the minimum amount, as well as the definition of each section displayed in the portal much sufficient and, may not encourage the taxpayers to gain tax knowledge rather than simply rely upon under the displayed information in the portal. 


\section{CONCLUSION}

A comprehensive analysis of this paper was carried out on individual taxpayers' tax compliance behaviour by examining the seven potential determinants: changes in government policies, referral group, the role of LHDN, political affiliation, cultural influence, religiosity, and tax knowledge. Following an extensive review of related literature, and from the findings based on this paper, the study concludes the significant relationships with the above-mentioned factors except for religiosity and tax knowledge. An individual's social factor impact is clearly discussed with help statistical findings. Interestingly, not alike developed countries, religiosity has no significant relationship with tax compliance level in Malaysia, but it is negatively related to tax compliance behaviour (Refer to Table 5). Since Malaysians are integrated society regardless of ethnicity, the referral group influence is seen as important. One's actions are determined by the other which supports Kelman's Social Influence Theory. The favorable changes occur on existing policies or newly introducing policies to impress the Malaysian taxpayers, which eventually increases the tax compliance level. The better way the tax authorities' performance and the favorable perception individual has towards the ruling government encourage the taxpayers to comply with the tax system.

The finding of this study contributes to tax compliance literature and also fills the existing gap by explains the association between social factors and individual taxpayers' tax compliance behaviour in Malaysia. Based on the findings, social factor is also one of the most important factors to be considered to measure the individual taxpayers' tax compliance behaviour with the tax system. Hence, an improvement in individual taxpayers' social determinants (as discussed above) will ultimately inspire them to comply with the tax system. Earlier studies emphasized the future researchers to carry out a study on the variables which have been tested in this paper. However, this paper recommends future researchers to focus more on further measurement tools to be applied to measuring religiosity, cultural influence, and political influence. The recent news articles show that Malaysia still experiences tax non-compliance and under-reporting. Limited available resources will not allow the Inland Revenue Board to detect the real reasons behind non-compliance. Issues related to tax evasion or tax non-compliance behaviour is the fundamental search for policymakers. Thus, this paper achieves the need that existed earlier by finding the root cause of why non-compliance is still prevailing. Therefore, this study recognizes the most important factor, social, determinants that encourage and discourage taxpayers' decisions towards tax compliance in Malaysia. The collected findings will assist the government, especially the tax authority, during policy planning, help the administration to develop stronger compliance risk treatment, and also to adopt the "Right from the Start" model. In the end, this study has made a significant contribution to the field of taxation and especially tax compliance focusing on individual taxation.

\section{ACKNOWLEDGEMENTS}

The authors wish to thank Ministry of Higher Education for funding this research through the Fundamental Research Grant Scheme (F01/FRGS/1605/2017). 


\section{REFERENCES}

Ahangar, R., Bandpey, H., \& Rokny, H. (2011). An Investigation into the determinant of effective factors on tax evasion (Empirical study of Iran Tax Affairs Organisation). American Journal of Scientific research, 5(2), 99-113.

Ahmed, A., \& Kedir, S. (2015). Tax Compliance and its Determinant: The Case of Jimma Zone, Ethiopia. International Journal of Research in Social Sciences, 6(2), 2-15.

Alabede, J., Ariffin, Z., \& Idris, K. (2011). Determinants of tax compliance behaviour: A proposed model for Nigeria. International Research Journal of Finance and Economics, 78(11), 5-11.

Alm, J., \& Togler, B. (2006). Culture differences and tax morale in the United States and in Europe. Journal of economic psychology, 27(2), 224-246.

Alm, J., Cherry, T. M., Jones, M., \& Mckee, M. (2010). Taxpayer Information Assistance Services and Tax Compliance Behavior. Journal of Economic Psychology, 31(4), 577-586.

Amran, N., Aripin, N., \& Kasipillai, J. (2013). The Influence of Education on Tax Avoidance and Tax Evasion. eJournal of Tax Research, 1(2), 64-65.

Baldry, J. \& Kasipillai, J. (1998). What do Malaysian taxpayers know?. Malaysian Accountant, 2(7), 51-72.

Bhavish, S., Hema, S., \& Akshay, S. (2017). Tax Evasion and Economic Growth: Evidence from Mauritius. Journal of Public Economics, 3(7), 15-19.

Behavioural Insights Team (BIT). (2012). Applying Behavioural Insights to Reduce Fraud, Error and Debt. Retrieved from http://38r8om2xjhhl25mw24492dir.wpengine.netdnacdn.com/wp-content/uploads/2015/07/BIT_FraudErrorDebt_accessible.pdf

Berens, S., \& Schiller, A. V. (2016). Taxing Higher Incomes: What Makes The High-Income Earners Consent to More Progressive Taxation in Latin America?. Political Behaviour, 41(4), 703-729.

Braithwaite, V. (2009). Defiance in Taxation and Governance: Resisting and Dismissing Authority in a Democracy. UK, Cheltenham: Edward Elgar.

Chan, W.C., Troutman, S, C., \& Bryan, D. (2000). An expanded model of taxpayer compliance: Empirical evidence from United States and Hong Kong. Journal of International Accounting, Auditing and Taxation, 9(2), 83-103.

Ching, S. P. (2013). Determinants of tax non-compliance in Malaysia (Unpublished master's thesis). Universiti Tunku Abdul Rahman, Malaysia.

Chong, K. R., \& Arunachalam, M. (2019). Determinants of Enforced Tax Compliance: Empirical Evidence from Malaysia. Advances in Taxation, 25(4), 147-172.

Chukwudi, D. (2017). Determinants of Tax Compliance Under the Self-Assessment System in Private Secondary Schools: Evidence from Delta North Senatorial Zone. Research Journal of Finance and Accounting, 9(7), 10-17.

Coleman, C., \& Freeman, L. (1997). Cultural foundations of taxpayer attitudes to voluntary compliance. Australian Tax Forum, 13(3), 311-337.

Delaney, L., \& Harmon, C. (2009). Behavioural Economics and Taxation (memo). Dublin: University College Dublin.

Eriksen, K., \& Fallan, L. (1996). Tax knowledge and attitudes towards taxation: A report on a quasi-experiment. Journal of Economic Psychology, 17(3), 387-402.

Esteller, A., Piolatto, A., \& Rablen, M. D. (2017). Taxing High Income Earners: Tax Avoidance and Mobility. Tax System Analysis, 17(6), 1-32. 
Fagbemi, T. O., Uadiale, O. M., \& Noah, A. O. (2010). The Ethics of Tax Evasion: Perceptual Evidence from Nigeria. European Journal of Social Sciences, 5(3), 360-371.

Government Accountability Office (GAO). (2011). Tax Gap - Complexity and Taxpayer Compliance. Retrieved from https://www.gao.gov/products/GAO-11-747T

Gërxhani, K. (2007). Explaining Gender Differences in Tax Evasion: The Case of Tirana, Albania. Feminist Economics, 13(2), 119-155.

Grasmick, H. G., Bursik, R. J., \& Cochran, J. K. (1991). Render Unto Caesar What Is Caesar's: Religiosity and Taxpayers' Inclinations to Cheat. The Sociological Quarterly, 32(2), 251266.

Grewal, I. (2018). Responsibilities of Individual Income Tax - 3E Accounting Malaysia. Retrieved from https://www.3ecpa.com.my/resources/malaysia-taxation/individualincome-tax/responsibilities-of-individual/

Gupta, R. (2017). Relational Impact of Tax Practitioners' Behaviour Interaction and Service Satisfaction: Evidence from New Zealand. eJournal of Tax Research, 13(1), 76-107.

Harjito, D. A., Omar, M. R., Ariffin, A. N., \& Latiff, A. R. (2005). Tax Literacy Rate among taxpayers: Evidence from Malaysia. Indonesian Journal of Accounting and Auditing, 9(1), $2-10$.

Harris, J. R. (1989). Ethical values of individuals at different levels in the organizational hierarchy of a single firm. Journal of Business Ethics, 9(9), 741-750.

Hanefah, M. (1996). An Evaluation of the Malaysian Tax Administrative System and Taxpayers Perceptions towards Assessment System, Tax Law Fairness and Tax Law Complexity (Unpublished doctoral dissertation). Universiti Utara Malaysia, Malaysia.

Hasseldine, J., \& Hite, A. P. (2003). Framing, gender and tax compliance. Journal of Economic Psychology, 24(4), 517-533.

Hong, T. J. (2005). Statistical Techniques in Business Research: A Practical Approach. Kuala Lumpur: Pearson Prentice Hall.

Ho J. K., Loo E. C., \& Lim K. P. (2013). Perspective of non-taxpayers' perceptions on issues of ethics and equity in tax compliance. Malaysian Accounting Review, 5(2), 47-59.

Inland Revenue Warns of syndicate out to cheat taxpayers (2017, October 25). National News. Retrieved from http://dailyexpress.com.my/news.cfm?NewsID=120656

Kasipillai, J. (1999). Tax Implications on Derivative Financial Instruments: A Malaysian Perspective. The Asia-Pacific Journal of Taxation, 3(1), 20-30.

Kasipillai, J. (2002). Investigations and tax audit under the self-assessment system. The Chartered Secretary Malaysia, 16(22), 5-7.

Kasipillai, J. (2004). Malaysia: 2003 Year in Review. Tax Notes International, 33(1), 7-15.

Kasipillai, J., \& Shanmugam, M. (1995). Malaysia: Towards a 2020 Vision of Taxation. Asia Pacific Tax Bulletin, 1(12), 5-15.

Keen, M., Kim, Y., \& Varsano, R. (2006). The "Flat Tax(es)": Principles and Evidence. International Monetary Fund, 6(18), 33-35.

Kelman, H. C. (1958). "Compliance, Identification, and Internalization: Three Processes of Attitude Change," Journal of Conflict Resolution, 2(1), 51-60.

Kelman, H. C. (2006). Interests, relationships, identities: three central issues for individuals and groups in negotiating their social environment. Annual Review of Psychology, 57(4), 1-26.

Kiow, T. S., Salleh, M. F. M., \& Kassim, A. A. (2017). The Determinants of Individual Taxpayers' Tax Compliance Behaviour in Peninsular Malaysia. International Business and Accounting Research Journal, 1(1), 26-43. 
Kirchler, E., Hoelzl, E., \& Wahl, I. (2008). Enforced versus voluntary tax compliance: The 'slippery slope' framework. Journal of Economic Psychology, 29(2), 210-225.

Krejcie, R. V., \& Morgan, D. W. (1970). Determining sample size for research activities. The NEA Research Bulletin, 38(1), 99-100.

LHDN reveals cheating syndicate using its name and logo. (2017, October 24). The Sun Daily. Retrieved from https://www.thesundaily.my/archive/lhdn-reveals-cheating-syndicateusing-its-name-and-logo-JTARCH495869

Loo, E. C. (2006). Tax knowledge, tax structure and compliance: A report on a quasiexperiment. New Zealand Journal of Taxation Law and Policy, 12(2), 117-140.

Loo, E. C., Evans, C., \& Mckerchar, M. A., (2010). Challenges in Understanding Compliance Behaviour of Taxpayers in Malaysia. Asian Journal of Business and Accounting, 3(2), 101-117.

Luttmer, F. E. \& Singhal, M. (2014). Tax Morale. Journal of Economic Perspectives, 28(4), 149168.

Lymer, A., \& Oats, L. (2009). Taxation: Policy and Practice. Birmingham: Fiscal Publications.

Marziana, M., Ahmad, N., \& Deris, S.M., (2010). Perceptions of Taxpayers with Level of Compliance: A Comparison in the East Coast Region, Malaysia: Journal of Global Business and Economics, 1(1), 241-257.

McGee, R. W., \& Gelman, W. (2009). Opinions on the Ethics of Tax Evasion: A Comparative Study of the USA and Six Latin American Countries. Akron Tax Journal, 24(3), 6-7.

Ministry of Finance Malaysia. (2019). The Budget Speech Text. Retrieved from https://www1.treasury.gov.my/pdf/budget/speech/bs19.pdf

Modugu, K., \& Anyaduba, J. (2014). Impact of Tax Audit on Tax Compliance in Nigeria. International Journal of Business and Social Science, 5(9), 207-215.

Mukhlis, I., Utomo, H. S., \& Soesetio, Y. (2015). The Role of Taxation Education on Taxation Knowledge and Its Effect on Tax Fairness as well as Tax Compliance on Handicraft SMEs Sectors in Indonesia. International Journal of Financial Research, 6(4), 9-17.

Murphy, K. (2004). "The Role of Trust in Nurturing Compliance: A Study of Accused Tax Avoiders", Law and Human Behavior, 28(2), 187-209.

New Economic Foundation (NEF). (2005). Behavioural Economics: Seven Principles for PolicyMakers. Retrieved from https://neweconomics.org/uploads/files/cd98c59233 42487571_v8m6b3g15.pdf

Nokman, F. S. (2017, April 13). Exclusive: IRB 'cheated of billions'. The Straits Times. Retrieved from https:/www.nst.com.my/news/nation/2017/04/230018/exclusive-irb-cheated-billions

Organization for Economic and Cooperation Development (OECD). (2010). Understanding and Influencing Taxpayers, Compliance Behaviour. Retrieved from https://www.oecd.org/tax/administration/46274793.pdf

Oladipupo, A. O., \& Obazee, U. (2016). Tax Knowledge, Penalties and Tax Compliance in Small Medium Scale Enterprises in Nigeria. iBusiness, 8(1), 1-9.

Olaoye, C. O. (2017). Tax Information, Administration and Knowledge on TaxPayers' Compliance of Block Moulding Firms in Ekiti State. Journal of Finance and Accounting, 5(4), 131-146.

Palil, M. (2010). Tax Knowledge and Tax Compliance Determinants in Self-Assessment System in Malaysia (Unpublished doctoral dissertation). University of Birmingham, UK

Palil, M. R., \& Mustapha, A. F. (2011). Determinants of tax compliance in Asia: A case of Malaysia. European Journal of Social Sciences, 24(1), 7-32. 
Palil, M. R., Hamid, M. A., \& Hanafiah, M. H. (2013). Taxpayers Compliance Behavior: Economic Factor Approach. Jurnal Pengurusan, 38(13), 75-85.

Petee, T. A., Milner, T. F., \& Welch, M. R. (1994). Levels of Social Integration in Group Contexts and the Effects of Informal Sanction Threat on Deviance. Criminology, 32(1), 85-106.

Piaw, C. Y. (2013). Mastering Research Statistics. Malaysia: McGraw Hill Education.

Pope, J., \& Jabbar, H. (2011). Tax Compliance Costs of Small and Medium Enterprises in Malaysia: Policy Implications (Unpublished doctoral dissertation). Curtin University, Malaysia.

Reeson, A., \& Dunstall, S. (2009). Behavioural Economics and Complex Decision-Making: Implications for the Australian Tax and Transfer System. Australia: CSIRO Mathematical and Information Sciences.

Riahi, A. (2004). Relationship between tax compliance internationally and selected determinants of tax morale. Journal of International Accounting, Auditing and Taxation, 13(2), 135 143.

Richardson, G. (2008). The relationship between culture and tax evasion across countries: Additional evidence and extensions. Journal of International Accounting, Auditing and Taxation, 17(2), 67-78.

Roberts, L. M., Hite, P. A., \& Bradley, C. F. (1994). Understanding attitudes toward progressive taxation. Public Opinion Quarterly, 58(2), 165-190.

Ross, M. A., \& McGee, R. W. (2011). Attitudes toward Tax Evasion: A Demographic Study of Malaysia. Asian Journal of Law and Economics, 2(3), 6-14.

Sekaran, U. (2000). Research Methods for Business: A Skill Building Approach. New York: John Wiley and Sons.

Sekaran, U. (2005). Cram 101 textbook outlines to accompany. Moorpark: Canada.

Serem, W., Robert, K., \& Phillip, O. (2017). The Effect of Tax System Simplicity on Tax Compliance Among the Rental Income Earners in Kenya. A Case of Eldoret Central Business District. European Journal of Business and Innovation Research, 5(5), 13-22.

Shah, A. (2017, November 23). Tax dodgers may be put in credit blacklist. New Straits Times. Retrieved from https://www.nst.com.my/news/exclusive/2017/11/304535/tax-dodgersmay-be-put-creditblacklist

Swedish Tax Agency (STA). (2005). Right from The Start-Research and Strategies. Retrieved from https://sweden.se/society/why-swedes-are-okay-with-paying-taxes/

Torgler, B. (2003). Tax moral and institutions. Centre for Research in Economics, Management and the Arts, 14(2), 119-140.

Torgler, B. (2004). Moral suasion: An alternative tax policy strategy? Evidence from a controlled field experiment in Switzerland. Economics of Governance, 5(3), 235-253.

Torgler, B. (2005). Tax morale and direct democracy. European Journal of Political economy, 21(2), 525-531.

Torgler, B. (2006). The importance of faith: Tax morale and religiosity. Journal of Economic Behaviour \& Organization, 61(1), 81-109.

Torgler, B. (2007). Tax Compliance and Tax Morale: A Theoretical and Empirical Analysis (Unpublished doctoral dissertation). University of Zurich, Switzerland.

Venkatesh, V., \& Davis, F. D. (2000). A Theoretical Extension of the Technology Acceptance Model: Four Longitudinal Field Studies, Management Science, 46(2), 186-204.

Walsh, K. (2012). Understanding Taxpayer Behaviour - New Opportunities for Tax Administration. The Economic and Social Review, 43(3), 7-12. 
Wang, L. (2015). Tax Enforcement, Corporate Tax Aggressiveness, and Cash Holdings. China Finance Review International, 5(4), 339-370.

Welch, M. R, Tittle, C. R., \& Petee, T. (1991). Religion and Deviance among Adult Catholics: A Test of the Moral Communities" Hypothesis. Journal for the Scientific Study of Religion, 30(2), 157-159.

Welch, M. R., Xu, Y., \& Magro, P. (2005). But Everybody Does It: The Effects of Perceptions, Moral Pressures, And Informal Sanctions on Tax Cheating. Sociological Spectrum, 25(1), 21-52.

Wenzel, M. (2001a). Misperceptions of Social Norms about Tax Compliance (1): A prestudy. Centre for Tax System Integrity Working Paper 7. Canberra: The Australian National University.

Wenzel, M. (2001b). Misperceptions of Social Norms about Tax Compliance (2): A field experiment. Centre for Tax System Integrity Working Paper 8. Canberra: The Australian National University.

Wenzel, M. (2005). Misperceptions of social norms about tax compliance: From theory to intervention. Journal of Economic Psychology, 26(6), 862-883.

World Bank. (2018). Malaysia: Tax revenue. Retrieved from https://data.worldbank.org/indicator/GC.TAX.TOTL.GD.ZS.

World Bank. (2020). Malaysia Gross National Income | 2005-2020 Data | 2021-2022 Forecast | Historical. Retrieved from https://tradingeconomics.com/malaysia/grossnationalproduct \#: :text=In\%20the \%20long-term\%2C\%20the\%20Malaysia\%20Gross $\% 20$ National $\% 20$ Income, in\%202022\%2C\%20according\%20to\%20our\%20econometric\%20models.\%203Y

Zandi, G., \& Elwahi, A. S. (2016). Tax Compliance Audit: The perspective of tax auditors in Malaysia. Asian Development Policy Review, 4(4),143-149. 